\author{
M.B. Muratbekov ${ }^{1}$, M.M. Muratbekov ${ }^{2}$ \\ ${ }^{1}$ Taraz State Pedagogical University, Kazakhstan; \\ ${ }^{2}$ Kazakh University of Economics, Finance and International Trade, Nur-Sultan, Kazakhstan \\ (E-mail: mmuratbekov@kuef.kz)
}

\title{
On the bounded invertibility of a Schrödinger operator with a negative parameter in the space $L_{2}\left(R^{n}\right)$
}

\begin{abstract}
The Schrödinger operator $L=-\Delta+q(x), x \in R^{n}$, is one of the main operators of modern quantum mechanics and theoretical physics. It is known that many fundamental results have been obtained for the Schrödinger operator $L$. Among them, for example, are questions about the existence of a resolvent, separability (coercive estimate), various weight estimates, estimates of intermediate derivatives of functions from the domain of definition of an operator, estimates of eigenvalues and singular numbers ( $s$-numbers). At present, there are various generalizations of the above results for elliptic operators. For general differential operators, the solution of such problem as a whole is far from complete. In particular, as far as we know, there was no result until now showing the existence of the resolvent and coercivity, as well as the discreteness of the spectrum of a hyperbolic type operator in an infinite domain with increasing and oscillating coefficients. It is easy to see that the study of some classes of differential operators of hyperbolic type defined in the space $L_{2}\left(R^{n+1}\right)$, using the Fourier method, can be reduced to the study of the Schrödinger operator with a negative parameter : $L_{t}=-\Delta+\left(-t^{2}+i t b(x)+q(x)\right)$, where $t$ is a parameter $(-\infty<t<\infty), i^{2}=-1$. Hence, it is easy to see that we get $-t^{2} \rightarrow-\infty$ when $|t| \rightarrow \infty$ for the operator $L_{t}$. Consequently, a completely different situation arises here compared to the Schrödinger operator $L=-\Delta+q(x)$, and in particular, the methods worked out for the Schrödinger operator $L$ turn out to be little adapted when studying the Schrödinger operator $L_{t}$ with a negative parameter. All these questions indicate the relevance and novelty of this work. In the paper we study the problems of the existence of the resolvent and the coercivity of the Schrödinger operator with a negative parameter.
\end{abstract}

Keywords: Schrödinger operator, singular differential operator, hyperbolic type, negative parameter, coercive estimates, resolvent.

\section{Formulation of the main results}

In the paper, the Schrödinger operator with negative parameter

$$
L_{t}=-\Delta+\left(-t^{2}+i t b(x)+q(x)\right)
$$

is studied in the space $L_{2}\left(R^{n}\right)$. Here, $-\infty<t<\infty, i^{2}=-1, \Delta$ is the Laplace operator, $x=\left(x_{1}, x_{2}, \ldots, x_{n}\right) \in R^{n}$.

The operator $L_{t}$, as is easily seen, arises naturally in the study of singular differential operators of hyperbolic type in the space $L_{2}\left(R^{n+1}\right)$.

As is well known the existence of the resolvent (self-adjointness) of the Schrödinger operator $\Delta+q(x)$ for $t=0$ is sufficiently well studied in research of T. Kato [1], M. Reed and B. Simon [2], B.M. Levitan, M. Otelbaev [3], M. Otelbaev [4, 5], R.S. Ismagilov [6], F.A. Berezin, M.A. Shubin [7], K.Kh. Boymatov [8], C.F. Yang [9], A. Zettl [10], T. Iwabuchi, T. Matsuyama, K. Tanigichi [11] and others.

The existence of the resolvent for $q(x)=q_{1}(x)+i q_{2}(x) \quad q_{1}(x) \geq 0, q_{2}(x) \geq 0$ is investigated in the papers of V.B. Lidskii [12], M. Otelbaev [5] and others.

Naturally, a similar question should be investigated for the operator $L_{t}$, i.e. should be studied the question: does there exist a bounded inverse operator $L_{t}^{-1}$ for all $t \in(-\infty ; \infty)$ ? Also the question of coercive estimates for the operator $L_{t}$ has been studied in the paper.

We denote by $c, c_{0}, c_{1}, \ldots$ different constants (different in different places), which exact values are not important to us; $R^{n}$ is $n$-dimensional real Euclidean space; $x=\left(x_{1}, x_{2}, \ldots, x_{n}\right)$ point in $R^{n} ;\|\cdot\|_{2}$ is the norm in $L_{2}\left(R^{n}\right) ; D\left(L_{t}\right)$ is a definition domain of the operator $L_{t} ; C_{0}^{\infty}\left(R^{n}\right)$ is a set of infinitely differentiable and compactly supported functions. Other notation will be introduced along the course of the exposition. 
Here are the formulations of the main results.

Consider the operator

$$
\left(L_{t}+\mu I\right) u=-\Delta u+\left(-t^{2}+i t b(x)+q(x)+\mu\right) u
$$

originally defined on the set $C_{0}^{\infty}\left(R^{n}\right)$, where $\mu \geq 0$.

Further, we assume that the coefficients $b(x), q(x)$ satisfy the conditions:

i) $|b(x)| \geq \delta_{0}>0, \quad q(x) \geq \delta>0$ are continuous functions in $R^{n}$.

The operator $L_{t}+\mu I$ admits closure in the space $L_{2}\left(R^{n}\right)$, which is also denoted by $L_{t}+\mu I$.

Theorem 1.1. Let the condition $i$ ) be fulfilled. Then the operator $L+\mu E$ is boundedly invertible for $\mu \geq 0$ in the space $L_{2}\left(R^{n}\right)$.

Theorem 1.2. Let the condition $i$ ) be fulfilled and $\mu \geq 0$. Then the following estimates

a) $\sum_{i=1}^{n}\left\|\frac{\partial u}{\partial x_{i}}\right\|_{2}+\|\sqrt{q(x)} u\|_{2} \leq c \cdot\left\|\left(L_{t}+\mu I\right) u\right\|_{2}$

b) $\sum_{i=1}^{n}\left\|\frac{\partial u}{\partial x_{i}}\right\|_{2}+\|\sqrt{q(x)} u\|_{2}+\|\sqrt{|t| \cdot b(x)} u\|_{2} \leq c \cdot\left\|\left(L_{t}+\mu I\right) u\right\|_{2}$ hold for all $u \in D\left(L_{t}\right)$ and all $|t| \geq \beta>0$, where $c>0$ is a constant.

\section{Auxiliary estimates and lemmas}

Lemma 2.1. Let the condition $i$ ) be fulfilled and $\mu \geq 0$. Then the estimate

$$
c(\delta) \cdot\left\|\left(L_{t}+\mu I\right) u\right\|_{2} \geq(\delta+\mu)^{1 / 2}\|u\|_{2}
$$

holds for all $u \in D\left(L_{t}\right)$, where $c(\delta)>0$.

Proof. Let $u \in C_{0}^{\infty}\left(R^{n}\right)$. Then the equality

$$
\begin{gathered}
\left\langle\left(L_{t}+\mu I\right) u, u\right\rangle=\int_{R^{n}}\left(-\Delta u+\left(-t^{2}+i t b(x)+q(x)+\mu\right) u\right) \cdot \bar{u} d x= \\
=\int_{R^{n}} \sum_{i=1}^{n}\left|\frac{\partial u}{\partial x_{i}}\right|^{2} d x+\int_{R^{n}}\left(-t^{2}+i t b(x)+q(x)+\mu\right)|u|^{2} d x,
\end{gathered}
$$

holds, where $\langle\cdot, \cdot\rangle$ is a scalar product in $L_{2}\left(R^{n}\right)$.

Hence we have that

$$
\left|\left\langle\left(L_{t}+\mu I\right) u, u\right\rangle\right| \geq \int_{R^{n}} \sum_{i=1}^{n}\left|\frac{\partial u}{\partial x_{i}}\right|^{2} d x+\int_{R^{n}}(q(x)+\mu)|u|^{2} d x-\int_{R^{n}} t^{2}|u|^{2} d x .
$$

The last inequality implies the following inequalities

$$
\begin{gathered}
\left|\left\langle\left(L_{t}+\mu I\right) u, u\right\rangle\right| \geq \int_{R^{n}} \sum_{i=1}^{n}\left|\frac{\partial u}{\partial x_{i}}\right|^{2} d x-\int_{R^{n}} t^{2}|u|^{2} d x \\
\left|\left\langle\left(L_{t}+\mu I\right) u, u\right\rangle\right| \geq \int_{R^{n}}(q(x)+\mu)|u|^{2} d x-\int_{R^{n}} t^{2}|u|^{2} d x .
\end{gathered}
$$

Using the Cauchy inequality with $\varepsilon>0$, here $\varepsilon=\frac{\delta}{2}$, we find from (2)

$$
\frac{1}{\delta}\left\|\left(L_{t}+\mu I\right) u\right\|_{2}^{2} \geq \frac{1}{2} \int_{R^{n}}(q(x)+\mu)|u|^{2} d x-\int_{R^{n}} t^{2}|u|^{2} d x .
$$

Further, we consider the following scalar product

$$
\left|\left\langle\left(L_{t}+\mu I\right) u,-i t u\right\rangle\right|=\left.\left|i t \int_{R^{n}}\left(\sum_{i=1}^{n}\left|\frac{\partial u}{\partial x_{i}}\right|^{2}+\left(-t^{2}+q(x)+\mu\right) \cdot|u|^{2}\right) d x+\int_{R^{n}} t^{2} b(x)\right| u\right|^{2} d x \mid .
$$


From (4) we find that

$$
\left|\left\langle\left(L_{t}+\mu I\right) u,-i t u\right\rangle\right| \geq \int_{R^{n}}|t|^{2}|b(x)||u|^{2} d x .
$$

Since $|b(x)| \geq \delta_{0}>0$ then we obtain from (5)

$$
\left|\left\langle\left(L_{t}+\mu I\right) u,-i t u\right\rangle\right| \geq t^{2} \cdot \delta_{0} \cdot\|u\|_{2}^{2} .
$$

Hence

$$
\left\|\left(L_{t}+\mu I\right) u\right\|_{2}^{2} \cdot \geq|t|^{2} \cdot \delta_{0}^{2} \cdot\|u\|_{2}^{2} .
$$

Multiplying both sides (6) by a number $c_{0}>0$ we have

$$
c_{0}\left\|\left(L_{t}+\mu I\right) u\right\|_{2}^{2} \geq c_{0} \cdot|t|^{2} \cdot \delta_{0}^{2} \cdot\|u\|_{2}^{2} .
$$

Combining (7) and (3) and choosing the number $c_{0}>0$ so that $|t|^{2} \delta_{0}^{2} c_{0}-|t|^{2} \geq 0$ we obtain that

$$
\left(c_{0}+\frac{1}{\delta}\right)\left\|\left(L_{t}+\mu I\right) u\right\|_{2}^{2} \geq \int_{R^{n}}(q(x)+\mu)|u|^{2} d x .
$$

Hence, taking into account the condition $i$ ), we find

$$
\sqrt{c(\delta)} \cdot\left\|\left(L_{t}+\mu I\right) u\right\|_{2} \geq(\delta+\mu)^{1 / 2}\|u\|,
$$

where $c(\delta)=\left(c_{0}+\frac{1}{\delta}\right)$. The inequality (1) is proved.

We take the collection of non-negative functions $\left\{\varphi_{j}\right\}, j \geq 1$ from $C_{0}^{\infty}\left(R^{n}\right)$ such that

$$
\sum_{j} \varphi_{j}^{2} \equiv 1, \sup p \varphi_{j} \subset \Delta_{j}, \bigcup_{j \geq 1} \Delta_{j} \equiv R^{n},
$$

where $\Delta_{j}$ - is open sets which intersection multiplicity is not higher than a some number $\xi=\xi(n)<\infty$. The existence of such coverage follows from the results of [13-15].

Continue $b(x), q(x)$ from $\Delta_{j}$ on the whole $R^{n}$ so that their continuations $b_{j}(x)$ and $q_{j}(x)$ are bounded and periodic functions of the same period.

By $L_{t, j, \alpha}+\mu I$ we denote the closure of the operator

$$
\left(L_{t, j, \alpha}+\mu I\right) u=-\Delta u+\left(-t^{2}+i t\left(b_{j}(x)+\alpha\right)+q_{j}(x)+\mu\right) \cdot u
$$

defined on $C_{0}^{\infty}\left(R^{n}\right)$, where the sign of the real number $\alpha$ coincides with the sign of the function $b(x)$, i.e. $\alpha \cdot b(x)>0$ for $x \in R^{n}$.

Lemma 2.2. Let the condition $i$ ) be fulfilled. Then for $\mu \geq 0$ the estimate

$$
c(\delta) \cdot\left\|\left(L_{t, j, \alpha}+\mu I\right) u\right\|_{L_{2}\left(R^{n}\right)} \geq(\delta+\mu)^{1 / 2}\|u\|_{L_{2}\left(R^{n}\right)}
$$

holds for all $u \in D\left(L_{t, j, \alpha}\right)$ in the space $L_{2}\left(R^{n}\right)$, where $c(\delta)>0$.

Proof. Let $u \in C_{0}^{\infty}\left(R^{n}\right)$. Then we have

$$
\left|\left\langle\left(L_{t, j, \alpha}+\mu I\right) u, u\right\rangle\right| \geq\left.\left|\int_{R^{n}} \sum_{i=1}^{n}\right| \frac{\partial u}{\partial x_{i}}\right|^{2} d x+\int_{R^{n}}\left[q_{j}(x)+\mu\right] \cdot|u|^{2} d x|-| \int_{R^{n}} t^{2}|u|^{2} d x \mid .
$$

Hence we have the following inequalities

$$
\begin{gathered}
\left\|\left(L_{t, j, \alpha}+\mu I\right) u\right\|_{L_{2}\left(R^{n}\right)} \cdot\|u\|_{2} \geq \int_{R^{n}} \sum_{i=1}^{n}\left|\frac{\partial u}{\partial x_{i}}\right|^{2} d x-\int_{R^{n}} t^{2}|u|^{2} d x ; \\
\frac{1}{\delta}\left\|\left(L_{t, j, \alpha}+\mu I\right) u\right\|_{2}^{2} \geq \frac{1}{2} \int_{R^{n}}\left[q_{j}(x)+\mu\right] \cdot|u|^{2} d x-t^{2} \int_{R^{n}}|u|^{2} d x .
\end{gathered}
$$

In the inequalities (10) we have used the Cauchy inequality with $\varepsilon>0$, where $\varepsilon=\frac{\delta}{2}$. 
Further, we consider the following scalar product

$$
\begin{gathered}
\left|\left\langle\left(L_{t, j, \alpha}+\mu I\right) u,-i t u\right\rangle\right|= \\
=\left.\left|-i t \int_{R^{n}} \sum_{i=1}^{n}\right| \frac{\partial u}{\partial x_{i}}\right|^{2} d x+\int_{R^{n}}\left[-t^{2}+q_{j}(x)+\mu\right] \cdot|u|^{2} d x+\int_{R^{n}} t^{2}\left(b_{j}(x)+\alpha\right)|u|^{2} d x \mid .
\end{gathered}
$$

Hence, and by virtue of the condition $\alpha \cdot b(x)>0$ we have for $x \in R^{n}$

$$
\left|\left\langle\left(L_{t, j, \alpha}+\mu I\right) u,-i t u\right\rangle\right| \geq t^{2} \int_{R^{n}}\left(\left|b_{j}(x)\right|+|\alpha|\right)|u|^{2} d x .
$$

From the last inequality we find that

$$
\left\|\left(L_{t, j, \alpha}+\mu I\right) u\right\|_{2}^{2} \geq|t|^{2}\left(\delta_{0}+|\alpha|\right)^{2} \cdot\|u\|_{2}^{2} .
$$

Combining the inequalities (10) and (11) and choosing $\alpha$ so that $\left(\delta_{0}+|\alpha|\right)^{2}-1 \geq 0$ we obtain

$$
\frac{1}{\delta}\left\|\left(L_{t, j, \alpha}+\mu I\right) u\right\|_{2}^{2}+\left\|\left(L_{t, j, \alpha}+\mu I\right) u\right\|_{2}^{2} \geq \frac{1}{2} \int_{R^{n}}\left[q_{j}(x)+\mu\right] \cdot|u|^{2} d x .
$$

From the inequality (12) we find that

$$
c(\delta)\left\|\left(L_{t, j, \alpha}+\mu I\right) u\right\|_{2} \geq \sqrt{\delta+\mu}\|u\|_{2},
$$

where $c(\delta)=\sqrt{2\left(\frac{1}{\delta}+1\right)}$. Lemma 2.2 is proved.

Lemma 2.3. Let the condition $i$ ) be fulfilled. Then for $\mu \geq 0$ the estimates

$$
\begin{gathered}
\left\|\left(L_{t, j, \alpha}+\mu I\right) u\right\|_{2}^{2} \geq \sum_{i=1}^{n}\left\|\frac{\partial u}{\partial x_{i}}\right\|_{2}^{2}+\left\|\sqrt{q_{j}(x)+\mu} u\right\|_{2}^{2} ; \\
\left\|\left(L_{t, j, \alpha}+\mu I\right) u\right\|_{2}^{2} \geq \sum_{i=1}^{n}\left\|\frac{\partial u}{\partial x_{i}}\right\|_{2}^{2}+\left\|\sqrt{q_{j}(x)+\mu} u\right\|_{2}^{2}+\left\|\sqrt{|t|\left(b_{j}(x)+|\alpha|\right)} u\right\|_{2}^{2}
\end{gathered}
$$

hold for all $u \in D\left(L_{t, j, \alpha}\right)$ and $|t| \geq \beta>0$, where $\beta>0$ is any positive number.

Proof. From the inequality (9), using the Cauchy inequality with $\varepsilon>0$, we have

$$
\frac{1}{2 \varepsilon}\left\|\left(L_{t, j, \alpha}+\mu I\right) u\right\|_{2}^{2}+\frac{\varepsilon}{2}\|u\|_{2}^{2} \geq \int_{R^{n}} \sum_{i=1}^{n}\left|\frac{\partial u}{\partial x_{i}}\right|^{2} d x-t^{2} \int_{R^{n}}|u|^{2} d x .
$$

Now we take $\varepsilon=\frac{\delta}{2}$. Then from the last inequality we obtain

$$
\frac{1}{\delta}\left\|\left(L_{t, j, \alpha}+\mu I\right) u\right\|_{2}^{2} \geq \sum_{i=1}^{n}\left\|\frac{\partial u}{\partial x_{i}}\right\|_{2}^{2}-\frac{\delta}{4}\|u\|_{2}^{2}-t^{2}\|u\|_{2}^{2} .
$$

From (11) and (15) we find that

$$
\frac{1}{\delta}\left\|\left(L_{t, j, \alpha}+\mu I\right) u\right\|_{2}^{2}+\left\|\left(L_{t, j, \alpha}+\mu I\right) u\right\|_{2}^{2} \geq \sum_{i=1}^{n}\left\|\frac{\partial u}{\partial x_{i}}\right\|_{2}^{2}-\frac{\delta}{4}\|u\|_{2}^{2}+\left(|t|^{2}\left(\delta_{0}+|\alpha|\right)^{2}-t^{2}\right) \cdot\|u\|_{2}^{2} .
$$

Hence, choosing $\alpha$ so that $|t|^{2}\left[\left(\delta_{0}+|\alpha|\right)^{2}-1\right] \geq 0$, we have

$$
\left(\frac{1}{\delta}+1\right)\left\|\left(L_{t, j, \alpha}+\mu I\right) u\right\|_{2}^{2} \geq \sum_{i=1}^{n}\left\|\frac{\partial u}{\partial x_{i}}\right\|_{2}^{2}-\frac{\delta}{4}\|u\|_{2}^{2} .
$$


From (16) and (12) we find that

$$
\begin{gathered}
\left(\frac{1}{\delta}+1\right)\left\|\left(L_{t, j, \alpha}+\mu I\right) u\right\|_{2}^{2}+\left(\frac{1}{\delta}+1\right)\left\|\left(L_{t, j, \alpha}+\mu I\right) u\right\|_{2}^{2} \geq \\
\geq \sum_{i=1}^{n}\left\|\frac{\partial u}{\partial x_{i}}\right\|_{2}^{2}-\frac{\delta}{4}\|u\|_{2}^{2}+\frac{1}{2} \int_{R^{n}}\left[q_{j}(x)+\mu\right] \cdot|u|^{2} d x .
\end{gathered}
$$

Hence

$$
\begin{gathered}
2\left(\frac{1}{\delta}+1\right)\left\|\left(L_{t, j, \alpha}+\mu I\right) u\right\|_{2}^{2} \geq \\
\geq \sum_{i=1}^{n}\left\|\frac{\partial u}{\partial x_{i}}\right\|_{2}^{2}-\frac{\delta}{4}\|u\|_{2}^{2}+\frac{1}{4} \int_{R^{n}}\left[q_{j}(x)+\mu\right] \cdot|u|^{2} d x+\frac{1}{4} \int_{R^{n}}\left[q_{j}(x)+\mu\right] \cdot|u|^{2} d x .
\end{gathered}
$$

From the last inequality we find

$$
8\left(\frac{1}{\delta}+1\right)\left\|\left(L_{t, j, \alpha}+\mu I\right) u\right\|_{2}^{2} \geq 4 \cdot \sum_{i=1}^{n}\left\|\frac{\partial u}{\partial x_{i}}\right\|_{2}^{2}+\left\|\sqrt{q_{j}(x)+\mu} u\right\|_{2}^{2} .
$$

Finally, we have

$$
c(\delta)\left\|\left(L_{t, j, \alpha}+\mu I\right) u\right\|_{2}^{2} \geq \sum_{i=1}^{n}\left\|\frac{\partial u}{\partial x_{i}}\right\|_{2}^{2}+\left\|\sqrt{q_{j}(x)+\mu} u\right\|_{2}^{2},
$$

where $c(\delta)=8\left(\frac{1}{\delta}+1\right)$. The inequality (13) is proved.

Prove the inequality (14). Let $u \in C_{0}^{\infty}\left(R^{n}\right)$. Then integrating by parts the scalar product

$$
\left|\left\langle\left(L_{t, j, \alpha}+\mu I\right) u, u\right\rangle\right| \geq\left.\left|\int_{R^{n}} i t\left(b_{j}(x)+\alpha\right)\right| u\right|^{2} d x \mid .
$$

Hence, by the condition $i$ ) and also taking the property $\alpha \cdot b(x)>0$ into account, we have for $x \in R^{n}$

$$
\frac{1}{2 \varepsilon}\left\|\left(L_{t, j, \alpha}+\mu I\right) u\right\|_{2}^{2} \geq \frac{1}{2} \int_{R^{n}}|t|\left(\left|b_{j}(x)\right|+|\alpha|\right)|u|^{2} d x+\frac{1}{2} \int_{R^{n}}\left[|t|\left(\left|b_{j}(x)\right|+|\alpha|\right)-\frac{\varepsilon}{2}\right] \cdot|u|^{2} d x .
$$

We have used here the Cauchy inequality with $\varepsilon>0$. Now, taking $|t| \geq \beta>0$ into account and choosing $\varepsilon>0$ so that $|t|\left(\delta_{0}+|\alpha|\right)-\frac{\varepsilon}{2} \geq 0$, we obtain the estimate

$$
c(\varepsilon)\left\|\left(L_{t, j, \alpha}+\mu I\right) u\right\|_{2}^{2} \geq\left\|\sqrt{|t|\left(\left|b_{j}(x)\right|+|\alpha|\right)} u\right\|_{2}^{2} .
$$

The estimate (14) follows from (13) and (17). Lemma 2.3 is completely proved.

Lemma 2.4. Operator $L_{t, j, \alpha}+\mu I$ for $\mu \geq 0$ has a continuous inverse operator $\left(L_{t, j, \alpha}+\mu I\right)^{-1}$ defined over the whole $L_{2}\left(R^{n}\right)$.

Proof. The estimate (8) implies that for the proof of Lemma 2.4 it suffices to show that the range of values $R\left(L_{t, j, \alpha}+\mu I\right)$ of the operator $L_{t, j, \alpha}+\mu I$ coincide with $L_{2}\left(R^{n}\right)$. We prove this by contradiction.

We assume that there exist an element $v \in L_{2}\left(R^{n}\right), v \neq 0$, such that for any $u \in D\left(L_{t, j, \alpha}\right)$

$$
\left\langle\left(L_{t, j, \alpha}+\mu I\right) u, v>=0 .\right.
$$

From the last equality we obtain

$$
\left(L_{t, j, \alpha}+\mu I\right)^{*} v=-\Delta v+\left(-t^{2}-i t\left(b_{j}(x)+\alpha\right)+q_{j}(x)+\mu\right) v=0
$$

in the sense of distributions. Since $b_{j}(x) v, q_{j}(x) v \in L_{2}\left(R^{n}\right)$, then (18) implies that $\Delta v \in L_{2}\left(R^{n}\right)$ for finite $t$, i.e. $v \in W_{2}^{2}\left(R^{n}\right)$. Now, if for any $v_{n} \in C_{0}^{\infty}\left(R^{n}\right)$ the inequality

$$
\left\|\left(L_{t, j, \alpha}+\mu I\right)^{*} v\right\|_{2} \geq c\|v\|_{2}
$$


holds, where $c>0$ is a constant then it also holds for the element $v \in W_{2}^{2}\left(R^{n}\right)$. Indeed, there exists a sequence $\left\{v_{n}\right\} \subset C_{0}^{\infty}\left(R^{n}\right)$ for $v \in W_{2}^{2}\left(R^{n}\right)$ converging to $v(x)$ in the norm $W_{2}^{2}\left(R^{n}\right)$. It is not difficult to prove that the inequality (19) holds for every $v_{n}(x)$. This is proved in exactly the same way as the inequality (8) in Lemma 2.2. Passing to the limit with respect to $n \rightarrow \infty$, we obtain, as is easy to see, the inequality (19) for $v(x)$ (this procedure is briefly called the closure of the inequality (19) in the norm $W_{2}^{2}\left(R^{n}\right)$ ), i.e.

$$
\left\|\left(L_{t, j}+\mu I\right)^{*} v\right\|_{2} \geq c\|v\|_{2} .
$$

Since $\left(L_{t, j, \alpha}+\mu I\right)^{*} v=0$, then the last inequality implies that $v \equiv 0$. Lemma 2.4 is proved.

Lemma 2.5. Let the condition $i$ ) be fulfilled and $\mu \geq 0$. Then the following inequalities

a) $\left\|\left(L_{t, j, \alpha}+\mu I\right)^{-1}\right\|_{2 \rightarrow 2} \leq \frac{c}{(\delta+\mu)^{1 / 2}}, \quad c=c(\delta)>0$

b) $\left\|D_{x_{i}}\left(L_{t, j, \alpha}+\mu I\right)^{-1}\right\|_{2 \rightarrow 2} \leq \frac{c}{(\delta+\mu)^{1 / 4}}, c=c(\delta)>0$

hold, where $D_{x_{i}}=\frac{\partial}{\partial x_{i}}$.

Proof. The estimate a) follows from the estimate (8). The estimate (8) also implies the inequality

$$
\frac{c(\delta)}{(\delta+\mu)^{1 / 2}}\left\|\left(L_{t, j, \alpha}+\mu I\right) u\right\|_{2} \geq\|u\|_{2}
$$

From the inequality (9), using the inequality (20), we find that

$$
\frac{c(\delta)}{\sqrt{(\delta+\mu)}}\left\|\left(L_{t, j, \alpha}+\mu I\right) u\right\|_{2}^{2} \geq \int_{R^{n}} \sum_{i=1}^{n}\left|\frac{\partial u}{\partial x_{i}}\right|^{2} d x-t^{2} \int_{R^{n}}|u|^{2} d x .
$$

Multiplying both sides of the inequality (11) by the number $\frac{1}{\sqrt{(\delta+\mu)}}$, we find the following inequality

$$
\frac{1}{\sqrt{(\delta+\mu)}}\left\|\left(L_{t, j, \alpha}+\mu I\right) u\right\|_{2}^{2} \geq \frac{|t|^{2}\left(\delta_{0}+|\alpha|\right)^{2}}{\sqrt{\delta+\mu}}\|u\|_{2}^{2} .
$$

Now combining (21) and (22), we obtain

$$
\frac{c(\delta)+1}{\sqrt{(\delta+\mu)}}\left\|\left(L_{t, j, \alpha}+\mu I\right) u\right\|_{2}^{2} \geq \int_{R^{n}} \sum_{i=1}^{n}\left|\frac{\partial u}{\partial x_{i}}\right|^{2} d x+|t|^{2} \int_{R^{n}}\left(\frac{\left(\delta_{0}+|\alpha|\right)^{2}}{\sqrt{\delta+\mu}}-1\right)|u|^{2} d x .
$$

Choosing $\alpha$ such that $\frac{\left(\delta_{0}+|\alpha|\right)^{2}}{\sqrt{\delta+\mu}}-1 \geq 0$, from the last inequality we find the estimate

$$
\frac{c(\delta)}{\sqrt{(\delta+\mu)}}\left\|\left(L_{t, j, \alpha}+\mu I\right) u\right\|_{2}^{2} \geq \sum_{i=1}^{n}\left|\frac{\partial u}{\partial x_{i}}\right|^{2}, c(\delta)=c(\delta)+1 .
$$

The estimate b) is proved. Lemma 2.5 is completely proved.

\section{Some estimates in the whole $R^{n}$}

We denote the closure of the differential expression

$$
\left(L_{t, \alpha}+\mu I\right) u=-\Delta u+\left(-t^{2}+i t(b(x)+\alpha)+q(x)+\mu\right) u
$$

in $L_{2}\left(R^{n}\right)$ by $L_{t, \alpha}+\mu I$, defined on the set $C_{0}^{\infty}\left(R^{n}\right)$.

Lemma 3.1. Let the condition $i$ ) be fulfilled and $\mu \geq 0$. Then the following inequalities

$$
\begin{gathered}
\left\|\left(L_{0, \alpha}+\mu I\right) u\right\|_{2} \geq(\delta+\mu) \cdot\|u\|_{2} \\
\left\|\left(L_{t, \alpha}+\mu I\right) u\right\|_{2} \geq|t|\left(\delta_{0}+|\alpha|\right) \cdot\|u\|_{2}, \quad t \neq 0,
\end{gathered}
$$

hold for all $u \in D\left(L_{t, \alpha}+\mu I\right)$. 
The inequalities (23) and (24) are proved by means of functionals $\left\langle\left(L_{0, \alpha}+\mu I\right) u, u\right\rangle,\left\langle\left(L_{t, \alpha}+\mu I\right) u, u\right\rangle$, $u \in C_{0}^{\infty}\left(R^{n}\right)$.

To prove the main theorems, in addition to the auxiliary lemmas given in sections 2 and 3, we use the following assertion [13-15].

Lemma 3.2. There exist a covering that has the following properties

a) $\sum_{\{j\}} \varphi_{j}^{2} \equiv 1, \varphi_{j} \in C_{0}^{\infty}\left(\Delta_{j}\right), \bigcup_{\{j\}} \Delta_{j} \equiv R^{n}$,

where $\Delta_{j}$ is a cube by an edge equal to 1 and center at the point $x_{j}=\left(x_{1}^{(j)}, x_{2}^{(j)}, \ldots, x_{n}^{(j)}\right)$;

b) $\left\|D_{x}^{\alpha} \varphi_{j}(x)\right\|_{C(R)} \leq c, c>0$ is a constant, $D_{x}^{\alpha}=\frac{\partial^{|\alpha|}}{\partial x_{1}^{\alpha_{1}}, \ldots, \partial x_{n}^{\alpha_{n}}}, \alpha=\left(\alpha_{1}, \alpha_{2}, \ldots, \alpha_{n}\right),|\alpha|=\alpha_{1}+\alpha_{2}+\ldots+\alpha_{n}$;

c) each set $\Delta_{j}$ can intersect with not more than $\xi(n)$ sets from the family $\left\{\Delta_{j}\right\}$, where $\xi(n)$ is some constant. Assume

$$
K_{\mu, \alpha} f=\sum_{\{j\}} \varphi_{j}\left(L_{t, j, \alpha}+\mu I\right)^{-1} \varphi_{j} f
$$

where $f \in L_{2}\left(R^{n}\right),\left\{\varphi_{j}\right\}$ is a set of functions from Lemma 3.2, $L_{t, j, \alpha}+\mu I$ is the operator from Lemma 2.2 .

It is easy to see that

$$
\left(L_{t, \alpha}+\mu I\right) K_{\mu, \alpha} f=f-B_{\mu, \alpha} f
$$

where

$$
B_{\mu, \alpha} f=\sum_{\{j\}} \Delta \varphi_{j}\left(L_{t, j, \alpha}+\mu I\right)^{-1} f+2 \sum_{\{j\}} \sum_{i=1}^{n} D_{x_{i}} \varphi_{j} D_{x_{i}}\left(L_{t, j, \alpha}+\mu I\right)^{-1} \varphi_{j} f, D_{x_{i}}=\frac{\partial}{\partial_{x_{i}}} .
$$

Lemma 3.3. Let the condition $i$ ) be fulfilled. Then there find a number $\mu_{0}>0$ such that

$$
\left\|B_{\mu, \alpha}\right\|_{L_{2}\left(R^{n}\right) \rightarrow L_{2}\left(R^{n}\right)}<1
$$

for all $\mu \geq \mu_{0}$.

Proof. Let $f \in C_{0}^{\infty}\left(R^{n}\right)$. Now, taking the multiplicity of the covering $\left\{\Delta_{j}\right\}$ into account, we have

$$
\begin{gathered}
\left\|B_{\mu, \alpha} f\right\|_{L_{2}\left(R^{n}\right)} \leq 2 \cdot\left(\left\|\sum_{\{j\}} \Delta \varphi_{j}\left(L_{t, j, \alpha}+\mu I\right)^{-1} \varphi_{j} f\right\|_{2}^{2}+\left\|2 \sum_{\{j\}} \sum_{i=1}^{n} D_{x_{i}} \varphi_{j} D_{x_{i}}\left(L_{t, j, \alpha}+\mu I\right)^{-1} \varphi_{j} f\right\|_{2}^{2}\right) \leq \\
\leq c_{1} \cdot\left(\sum_{\{j\}}\left\|\Delta \varphi_{j}\left(L_{t, j, \alpha}+\mu I\right)^{-1} \varphi_{j} f\right\|_{2}^{2}+\sum_{i=1}^{n} \sum_{\{j\}}\left\|D_{x_{i}} \varphi_{j} D_{x_{i}}\left(L_{t, j, \alpha}+\mu I\right)^{-1} \varphi_{j} f\right\|_{2}^{2}\right) \leq \\
\leq c_{1} \cdot\left(\sup _{\{j\}}\left\|\Delta \varphi_{j}\left(L_{t, j, \alpha}+\mu I\right)^{-1}\right\|_{2}^{2} \cdot \sum_{\{j\}}\left\|\varphi_{j} f\right\|_{2}^{2}+\sup _{1 \leq i \leq n} \sup _{\{j\}}\left\|D_{x_{i}} \varphi_{j} D_{x_{i}}\left(L_{t, j, \alpha}+\mu I\right)^{-1} \varphi_{j} f\right\|_{2}^{2}\right) .
\end{gathered}
$$

From this and from Lemma 2.5, taking $\left\|D_{x_{i}}^{\alpha} \varphi_{j}\right\|_{C(R)} \leq c, \alpha=0,1,2, \sum_{\{j\}}\left\|\varphi_{j} f\right\|^{2}=\|f\|_{2}^{2}$ into account, we obtain

$$
\left\|B_{\mu, \alpha} f\right\|_{2 \rightarrow 2}^{2} \leq c_{1} \cdot c\left[\frac{c^{2}(\delta)}{(\delta+\mu)}+\frac{c^{2}(\delta)}{(\delta+\mu)^{1 / 2}}\right] \cdot\|f\|_{L_{2}\left(R^{n}\right)}^{2} .
$$

From the last inequality it follows that one can find a number $\mu_{0}>0$ such that $\left\|B_{\mu, \alpha}\right\|_{2 \rightarrow 2}<1$ for $\mu \geq \mu_{0}$. Lemma 3.3 is proved.

Lemma 3.4. Let the condition $i$ ) be fulfilled. Then the operator $L_{t, \alpha}+\mu I$ is boundedly invertible for $\mu \geq \mu_{0}>0$, and the equality

$$
\left(L_{t, \alpha}+\mu I\right)^{-1}=K_{\mu, \alpha}\left(E-B_{\mu, \alpha} f\right)^{-1}
$$

holds for the inverse operator $\left(L_{t, \alpha}+\mu I\right)^{-1}$.

The proof of the lemma follows from the representation (25) using Lemmas 3.1 and 3.3.

Now we consider the solvability of the original operator $L_{t}+\mu I$. To do this, consider the following equation

$$
\left(L_{t}+\mu I\right) u=-\Delta u+\left(-t^{2}+i t b(x)+q(x)+\mu\right) u=f(x),
$$

where $f(x) \in L_{2}\left(R^{n}\right)$. 
Definition. The function $u \in L_{2}\left(R^{n}\right)$ is called a solution of the equation (27) if there exists a sequence $\left\{u_{n}\right\}_{n=1}^{\infty} \subset C_{0}^{\infty}\left(R^{n}\right)$ such that

$$
\left\|u_{n}-u\right\|_{L_{2}\left(R^{n}\right)} \rightarrow 0,\left\|\left(L_{t}+\mu I\right) u_{n}-f\right\|_{L_{2}\left(R^{n}\right)} \rightarrow 0
$$

as $n \rightarrow \infty$.

This shows that the inverse operator $\left(L_{t}+\mu I\right)^{-1}$ coincides with the closure of the operator $L_{t}+\mu I$ in $L_{2}\left(R^{n}\right)$ defined on $C_{0}^{\infty}\left(R^{n}\right)$.

Lemma 3.5. Let the condition $i$ ) be fulfilled. Then the operator $L_{t}+\mu I$ is boundedly invertible for $\mu \geq \mu_{0}>0$ and the equality

$$
\left(L_{t}+\mu I\right)^{-1} f=\left(L_{t, \alpha}+\mu I\right)^{-1}\left(E-A_{\mu, \alpha}\right)^{-1} f
$$

holds for the inverse operator $\left(L_{t}+\mu I\right)^{-1}$, where $f \in L_{2}\left(R^{n}\right),\left\|A_{\mu, \alpha}\right\|_{L_{2}\left(R^{n}\right) \rightarrow L_{2}\left(R^{n}\right)}<1$.

Proof. Let $t \neq 0$. The equation

$$
\left(L_{t}+\mu I\right) u=f
$$

can be rewritten as

$$
v-A_{\mu, \alpha} v=f
$$

where $v=\left(L_{t, \alpha}+\mu I\right) u, A_{\mu, \alpha}=i t \alpha\left(L_{t, \alpha}+\mu I\right)^{-1}$, where $i^{2}=-1$. Lemma 3.1 implies that

$$
\left\|A_{\mu, \alpha} v\right\|_{L_{2}\left(R^{n}\right)} \leq \frac{|t| \cdot|\alpha|}{|t|\left(\delta_{0}+|\alpha|\right)}
$$

Hence $\left\|A_{\mu, \alpha}\right\|_{L_{2}\left(R^{n}\right) \rightarrow L_{2}\left(R^{n}\right)}<1$.

(28), (29) implies that

$$
u=\left(L_{t}+\mu I\right)^{-1} f=\left(L_{t, \alpha}+\mu I\right)^{-1}\left(I-A_{\mu, \alpha}\right)^{-1} f
$$

for $t \neq 0$.

As is known, if $t=0$ then the operator is essentially self-adjoint [2] and the estimate

$$
\left\|\left(L_{0}+\mu I\right) u\right\|_{L_{2}\left(R^{n}\right)} \geq(\delta+\mu) \cdot\|u\|_{L_{2}\left(R^{n}\right)}
$$

holds for all $u \in D\left(L_{0}+\mu I\right)$. This implies that the operator $L_{0}+\mu I$ has a bounded inverse operator $\left(L_{0}+\mu I\right)^{-1}$ defined over the whole $L_{2}\left(R^{n}\right)$. Lemma 3.5 is completely proved.

Lemma 3.6. Let the condition $i$ ) be fulfilled and $\mu \geq 0$. Then the estimates

$$
\begin{gathered}
\left\|\left(L_{0}+\mu I\right) u\right\|_{L_{2}\left(R^{n}\right)} \geq \delta\|u\|_{L_{2}\left(R^{n}\right)}, \\
\left\|\left(L_{t}+\mu I\right) u\right\|_{L_{2}\left(R^{n}\right)} \geq|t| \cdot \delta_{0} \cdot\|u\|_{L_{2}\left(R^{n}\right)}, t \neq 0,
\end{gathered}
$$

hold for all $u \in D\left(L_{t}\right)$.

Proof. Lemma 3.6 is proved in exactly the same way as Lemma 3.1.

The following Lemma is well-known [16].

Lemma 3.7. Let the operator $L_{t}+\mu_{0} I\left(\mu_{0} \geq 0\right)$ is boundedly invertible in $L_{2}\left(R^{n}\right)$ and the estimate

$$
\left\|\left(L_{t}+\mu I\right) u\right\|_{L_{2}\left(R^{n}\right)} \geq c \cdot\|u\|_{L_{2}\left(R^{n}\right)}
$$

holds for all $u \in D\left(L_{t}+\mu I\right)$ when $\mu \in\left[0, \mu_{0}\right]$, where $c>0$ is a constant. Then the operator $L_{t}: L_{2}\left(R^{n}\right) \rightarrow$ $\rightarrow L_{2}\left(R^{n}\right)$ is also boundedly invertible.

Proof of Theorem 1.1. The proof follows from Lemmas 2.1, 3.5 and 3.7.

Lemma 3.8. Let the condition $i$ ) be fulfilled and $\mu \geq \mu_{0}$. Then the following estimates

a) $\|\sqrt{q(x)+\mu} u\|_{\left.L_{2}\right) R^{n}} \leq c \cdot\left\|\left(L_{t, \alpha}+\mu I\right) u\right\|_{\left.L_{2}\right) R^{n}}$;

b) $\left\|D_{x_{i}} u\right\|_{\left.L_{2}\right) R^{n}} \leq c \cdot\left\|\left(L_{t, \alpha}+\mu I\right) u\right\|_{\left.L_{2}\right) R^{n}}$,

hold for all $u \in D\left(L_{t, \alpha}\right)$, where $D_{x_{i}}=\frac{\partial}{\partial x_{i}}(i=1,2, \ldots, n), c>0$ is a constant. 
Proof. Let $f \in C_{0}^{\infty}\left(R^{n}\right)$. Then, taking the properties of the functions $\varphi_{j}(j \in Z)$ into account, from the representation of (26) we have

$$
\begin{gathered}
\left\|\sqrt{q(x)+\mu}\left(L_{t, \alpha}+\mu I\right)^{-1} f\right\|_{2}^{2}=\left\|\sqrt{q(x)+\mu} \sum_{\{j\}} \varphi_{j}\left(L_{t, j, \alpha}+\mu I\right)^{-1} \varphi_{j}\left(E-B_{\mu, \alpha}\right)^{-1} f\right\|_{2}^{2}= \\
=\left\|\sum_{\{j\}} \sqrt{q(x)+\mu} \cdot \varphi_{j}\left(L_{t, j, \alpha}+\mu I\right)^{-1} \varphi_{j}\left(E-B_{\mu, \alpha}\right)^{-1} f\right\|_{2}^{2} \leq \\
\leq\left\|\sum_{\{j\}} \sqrt{q_{j}(x)+\mu}\left(L_{t, j, \alpha}+\mu I\right)^{-1} \varphi_{j}\left(E-B_{\mu, \alpha}\right)^{-1} f\right\|_{2}^{2} .
\end{gathered}
$$

Here it was taken into account that the functions $\sqrt{q(x)+\mu} \cdot \varphi_{j}$ and $\sqrt{q_{j}(x)+\mu}$ coincide on the set $\Delta_{j}$.

Taking the finite multiplicity of the covering $\left\{\Delta_{j}\right\}$ and the inequality (13) into account, we obtain from (30)

$$
\begin{gathered}
\left\|\sqrt{q(x)+\mu}\left(L_{t, \alpha}+\mu I\right)^{-1} f\right\|_{2}^{2} \leq c \cdot \sum_{\{j\}}\left\|\sqrt{q_{j}(x)+\mu}\left(L_{t, j, \alpha}+\mu I\right)^{-1} \varphi_{j}\left(E-B_{\mu, \alpha}\right)^{-1} f\right\|_{2}^{2} \leq \\
\leq c \cdot \sup _{\{j\}}\left\|\sqrt{q_{j}(x)+\mu}\left(L_{t, j, \alpha}+\mu I\right)^{-1}\right\|_{2 \rightarrow 2}^{2} \cdot \sum_{\{j\}}\left\|\varphi_{j}\left(E-B_{\mu, \alpha}\right)^{-1} f\right\|_{2}^{2}
\end{gathered}
$$

From this and Lemmas 2.3 and 3.3 we finally have

$$
\left\|\sqrt{q(x)+\mu}\left(L_{t, \alpha}+\mu I\right)^{-1} f\right\|_{2}^{2} \leq c \cdot\|f\|_{2}^{2} .
$$

Whence

$$
\|\sqrt{q(x)+\mu} u\|_{L_{2}\left(R^{n}\right)}^{2} \leq c \cdot\left\|\left(L_{t, \alpha}+\mu I\right) u\right\|_{2}^{2},
$$

where $\left(L_{t, \alpha}+\mu I\right) u=f$. The item a) of Lemma 3.8 is proved.

Let us prove the item b) of Lemma 3.8.

$$
\begin{gathered}
\left\|D_{x_{i}}\left(L_{t, \alpha}+\mu I\right) f\right\|_{2}=\left\|D_{x_{i}} \sum_{j} \varphi_{j}\left(L_{t, j, \alpha}+\mu I\right)^{-1} \varphi_{j}\left(E-B_{\mu, \alpha}\right)^{-1} f\right\|_{2}^{2}= \\
=\left\|\sum_{\{j\}}\left(D_{x_{i}} \varphi_{j}\left(L_{t, j, \alpha}+\mu I\right)^{-1} \varphi_{j}\left(E-B_{\mu, \alpha}\right)^{-1} f+\varphi_{j} D_{x_{i}}\left(L_{t, j, \alpha}+\mu I\right)^{-1} \varphi_{j}\left(E-B_{\mu, \alpha}\right)^{-1} f\right)\right\|_{2}^{2} \leq \\
\leq c\left(\sum_{\{j\}}\left\|D_{x_{i}} \varphi_{j}\left(L_{t, j, \alpha}+\mu I\right)^{-1} \varphi_{j}\left(E-B_{\mu, \alpha}\right)^{-1} f\right\|_{2}^{2}+\right. \\
\left.+\sum_{\{j\}}\left\|\varphi_{j} D_{x_{i}}\left(L_{t, j, \alpha}+\mu I\right)^{-1} \varphi_{j}\left(E-B_{\mu, \alpha}\right)^{-1} f\right\|_{2}^{2}\right) .
\end{gathered}
$$

Here we took the finite multiplicity of the covering $\left\{\Delta_{j}\right\}$ into account.

From the last inequality we have

$$
\begin{aligned}
\| D_{x_{i}}\left(L_{t, \alpha}+\right. & \mu I) f \|_{\left.L_{2}\right) R^{n}}^{2} \leq c\left(\sup _{\{j\}}\left\|D_{x_{i}} \varphi_{j}\left(L_{t, j, \alpha}+\mu I\right)^{-1}\right\|_{2}^{2} \cdot \sum_{\{j\}}\left\|\varphi_{j}\left(E-B_{\mu, \alpha}\right)^{-1} f\right\|_{2}^{2}+\right. \\
& \left.+\sup _{\{j\}}\left\|\varphi_{j} \cdot D_{x_{i}}\left(L_{t, j, \alpha}+\mu I\right)^{-1}\right\|_{2}^{2} \cdot \sum_{\{j\}}\left\|\varphi_{j}\left(E-B_{\mu, \alpha}\right)^{-1} f\right\|_{2}^{2}\right) \leq \\
& \leq c\left(\tilde{c}_{1} \sup _{\{j\}}\left\|\left(L_{t, j, \alpha}+\mu I\right)^{-1}\right\|_{2}^{2} \cdot \sum_{\{j\}}\left\|\varphi_{j}\left(E-B_{\mu, \alpha}\right)^{-1} f\right\|_{2}^{2}+\right. \\
& \left.+\tilde{c}_{0} \sup _{\{j\}}\left\|D_{x_{i}}\left(L_{t, j, \alpha}+\mu I\right)^{-1}\right\|_{2}^{2} \cdot \sum_{\{j\}}\left\|\varphi_{j}\left(E-B_{\mu, \alpha}\right)^{-1} f\right\|_{2}^{2}\right)
\end{aligned}
$$

where $\tilde{c}_{1}=\sup _{\{j\}}\left(\max _{x \in R^{n}}\left|\varphi_{j}^{\prime}\right|\right), \quad \tilde{c}_{0}=\sup _{\{j\}}\left(\max _{x \in R^{n}}\left|\varphi_{j}\right|\right)$.

From this and from Lemma 2.5 we find that

$$
\begin{gathered}
\left\|D_{x_{i}}\left(L_{t, \alpha}+\mu I\right) f\right\|_{\left.L_{2}\right) R^{n}}^{2} \leq c\left(\frac{\tilde{c}_{1} \cdot c(\delta)}{\delta+\mu} \cdot\left\|\left(E-B_{\mu, \alpha}\right)^{-1}\right\|_{2 \rightarrow 2}^{2} \cdot\|f\|_{L_{2}\left(R^{n}\right)}^{2}+\right. \\
\left.+\tilde{c}_{0} \cdot \frac{c(\delta)}{(\delta+\mu)^{1 / 2}} \cdot\left\|\left(E-B_{\mu, \alpha}\right)^{-1}\right\|_{2 \rightarrow 2}^{2} \cdot\|f\|_{L_{2}\left(R^{n}\right)}^{2}\right) .
\end{gathered}
$$


Lemma 3.3 implies that the operator $\left(E-B_{\mu, \alpha}\right)^{-1}$ is bounded in $L_{2}\left(R^{n}\right)$. Consequently, from the last inequality we finally have

$$
\left\|D_{x_{i}} u\right\|_{\left.L_{2}\right) R^{n}}^{2} \leq c^{2}\left\|\left(L_{t, \alpha}+\mu I\right) u\right\|_{L_{2}\left(R^{n}\right)}^{2},
$$

where $\left(L_{t, \alpha}+\mu I\right) u=f, \quad i=1,2,3, \ldots, n$. Lemma 3.8 is proved.

Proof of Theorem 1.2. The proof of Theorem 1.2 follows from Lemmas 2.3, 3.5 and 3.8.

\section{References}

1 Kato T. Schrödinger operators with singular potentials / T. Kato // Isr. J. Math. - 1972. - 13. No. 1-2. - P. 135-148.

2 Рид М. Методы современной математической физики: гармонический анализ, самосопряженность / М. Рид, Б. Саймон. - Т. 2. - М.: Мир, 1978. - 396 с.

3 Левитан Б.М. Об условиях самосопряженности операторов Шредингера и Дирака / Б.М. Левитан, М. Отелбаев // Докл. АН СССР. - 1977. - 235. - № 4. - С. 768-771.

4 Отелбаев М. Об условиях самосопряженности операторов Шредингера с операторным потенциалом / М. Отелбаев // Укр. мат. журн. - 1976. - 28. - № 6. - С. 763-771.

5 Отелбаев М. Оценки спектра оператора Штурма-Лиувилля / М. Отелбаев. - Алма-Ата: Ғылым, 1990. - $190 \mathrm{c}$.

6 Исмагилов Р.С. Об условиях самосопряженности дифференциальных операторов высшего порядка / Р.С. Исмагилов // Докл. АН СССР. - 1962. - 142. - № 6. - С. 1239-1242.

7 Березин Ф.А. Уравнение Шредингера / Ф.А. Березин, М.А. Шубин. - М.: Изд-во МГУ, 1983. $392 \mathrm{c}$.

8 Бойматов К.X. Асимптотика спектра эллиптического дифференциального оператора в вырожденном случае / К.Х. Бойматов // Докл. АН СССР. - 1982. - 266. - № 1. - С. 14.

9 Yang C.F. New trace formulae for a quadratic pencil of the Schrödinger operator / C.F. Yang // Journal of Mathematical Physics. - 2010. - 51. - P. 33506.

10 Zettl A. Sturm-Liouville theory: Mathematical Surveys and Monographs / A. Zettl // American Mathematical Society, Providence. - 2005. - 121.

11 Iwabuchi T. $L^{p}$-boundedness of Schrödinger operators on an open set of $R^{d} /$ T. Iwabuchi, T. Matsuyama, K. Tanigichi // New Trends in Analysis and Interdisciplinary Applications. Selected contributions of the $10^{\text {th }}$ ISAAC congress. Springer Int. Publ. - 2017. - P. 319-325.

12 Лидский В.Б. Несамосопряженный оператор типа Штурма-Лиувилля с дискретным спектром / В.Б. Лидский // Труды Москов. матем. общества. - 1960. - 9. - С. 45-80.

13 Guzman M. Differentiation of integrals in $R^{n}$ / M.Guzman. - Berlin |Heidleberq| New York: SpringerVerlaq. - 1975.

14 Отелбаев М. Коэрцитивные оценки и теоремы разделимости для эллиптических уравнений в $R^{n}$ / М. Отелбаев // Труды Мат. ин-та АН СССР им. В.А. Стеклова. - 1983. - 161. - С. 195-217.

15 Muratbekov M. On the existence of a resolvent and separability for a class of singular hyperbolic type differential operators on an unbounded domain / M. Muratbekov, M. Otelbaev // Eurasian mathematical Journal. - 2011. - 7. - No. 1. - P. 50-67.

16 Akhieser N.I. Theory of linear operators in Hilbert space / N.I. Akhieser, I.M. Glasman. Originally published: New York: Unqar Pub. - 1963. - 378 p. 
М.Б. Мұратбеков, М.М. Мұратбеков

\section{$L_{2}\left(R^{n}\right)$ кеңістігінде теріс параметрлі Шрёдингер оператор үшін шектеулі кері операторының бар болуы жайлы}

$L=-\Delta+q(x), x \in R^{n}$, Шрёдингер операторы қазіргі кванттық механиканың және теориялық физиканың негізгі операторларының бірі болып табылады. $L$ Шрёдингер операторы үшін көптеген іргелі нәтижелер алынды. Олардың ішінде, мысалы, шешілуі, бөлгіштігі (коэрцитивті бағалаулар), әртүрлі салмақтық бағалар, оператордың анықталу облысы бойынша аралық туындылардың бағалауы, меншікті мәндер және сингулярлық сандар ( $s$-сандар) туралы мәселелер бар. Қазіргі кезде эллиптикалық операторлар үшін жоғарыда келтірілген нәтижелердің әртүрлі қорытындылары бар. Жалпы дифференциалды операторлар үшін бұл мәселенің шешілуі толық аяқталмаған. Атап айтқанда, біздің біліуміз бойынша, резольвентасының бар болуы мен коэрцитивтігі, сондай-ақ шексіз облыста өспелі және тербелісті коэффициенттерімен гиперболалық типті оператордың спектрінің дискретілігін көрсететін нәтиже болмады. Әрине, $L_{2}\left(R^{n+1}\right)$ кеңістігінде анықталған гиперболалық типті дифференциалдық операторлардың кейбір кластарының зерттеуін Фурье әдісі арқылы теріс параметрлі Шрёдингер операторын зерттеуге алып келуге болады: $L_{t}=-\Delta+\left(-t^{2}+i t b(x)+q(x)\right)$, мұндағы $t-(-\infty<t<\infty), i^{2}=-1$ параметрі. Демек, $L_{t}$ операторында $|t| \rightarrow \infty$ болса, онда $-t^{2} \rightarrow-\infty$ екенін көру қиын емес. Демек, мұнда, $L=-\Delta+q(x)$ Шрёдингер операторына карағанда, мүлдем басқа жағдай пайда болады, соның ішінде $L$ Шрёдингер операторы үшін әзірленген әдістер $L_{t}$ теріс параметрлі Шрёдингер операторына жарамсыз болып қалады. Барлық бұл мәселелер осы жұмыстың өзектілігі мен жаңалығын көрсетті. Осы мақалада теріс параметрлі Шрёдингер операторының резольвентасының бар болуы және коэрцитивтілігі жан-жақты зерттелді.

Kiлm сөздер: Шрёдингер операторы, сингулярлы диффренциалдық оператор, гиперболалық оператор, теріс параметр, коэрцитивті бағалаулар, резольвента.

\section{М.Б. Муратбеков, М.М. Муратбеков}

\section{Об ограниченной обратимости оператора Шрёдингера с отрицательным параметром в пространстве $L_{2}\left(R^{n}\right)$}

Оператор Шрёдингера $L=-\Delta+q(x), x \in R^{n}$, является одним из основных операторов современной квантовой механики и теоретической физики. Известно, что для оператора Шрёдингера $L$ получено немало фундаментальных результатов. Среди них, например, вопросы о существовании резольвенты, разделимости (коэрцитивная оценка), различные весовые оценки, оценки промежуточных производных функций из области определения оператора, оценки собственных и сингулярных чисел ( $s$-чисел). В настоящее время имеются различные обобщения указанных выше результатов для эллиптических операторов. Для общих дифференциальных операторов решение такой задачи в целом далеко от завершения. В частности, насколько нам известно, до сих пор не было результата, показывающего существование резольвенты и коэрцитивности, а также дискретности спектра оператора гиперболического типа в бесконечной области с растущими и колеблющимися коэффициентами. Нетрудно заметить, что изучение некоторых классов дифференциальных операторов гиперболического типа, определенных в пространстве $L_{2}\left(R^{n+1}\right)$, можно свести с помощью метода Фурье к изучению оператора Шрёдингера с отрицательным параметром: $L_{t}=-\Delta+\left(-t^{2}+i t b(x)+q(x)\right)$, где $t$ - параметр $(-\infty<t<\infty), i^{2}=-1$. Отсюда ясно, что в операторе $L_{t}$ при $|t| \rightarrow \infty--t^{2} \rightarrow-\infty$. Следовательно, здесь возникает совершенно иная ситуация по сравнению с оператором Шрёдингера $L=-\Delta+q(x)$, и, в частности, методы, отработанные для оператора Шрёдингера $L$, оказываются мало приспособленными при изучении оператора Шрёдингера $L_{t}$ с отрицательным параметром. Все эти вопросы свидетельствуют об актуальности и новизне данной работы. В настоящей статье изучены вопросы существования резольвенты и коэрцитивности оператора Шрёдингера с отрицательным параметром.

Ключевые слова: оператор Шрёдингера, сингулярный дифференциальный оператор, гиперболический оператор, отрицательный параметр, коэрцитивные оценки, резольвента. 


\section{References}

1 Kato, T. (1972). Schrödinger operators with singular potentials. Isr. J. Math., 13, 1-2, 135-148.

2 Reed, M. \& Saimon, B. (1978). Metody sovremennoi matematicheskoi fiziki: harmonicheskii analiz, samosopriazhennost [Methods of modern mathematical physics: Harmonic analysis, self-adjointness]. Moscow: Mir [in Russian].

3 Levitan, B.M. \& Otelbaev, M. (1977). Ob usloviiakh samosopriazhennosti operatorov Shredinhera i Diraka [On conditions of self-adjointness of the Schrödinger and Dirac operators]. Doklady AN SSSR - Reports of the USSR Academy of Sciences, 235, 4, 768-771 [in Russian].

4 Otelbaev, M. (1976). Ob usloviiakh samosopriazhennosti operatorov Shredinhera s operatornym potentsialom [On conditions of self-adjointness of Schrödinger operators with operator potential]. Ukrainskii matematicheskii zhurnal - Ukrainian Mathematical Journal, 28, 6, 763-771 [in Russian].

5 Otelbaev, M. (1990). Otsenki spektra operatora Shturma-Liuvillia [Estimates of the spectrum of the SturmLiouville operator]. Almaty: Hylym [in Russian].

6 Ismagilov, R.S. (1962). Ob usloviiakh samosopriazhennosti differentsialnykh operatorov vysshego poriadka. [Self-adjointness conditions of higher-order differential operators] Doklady AN SSSR - Reports of the USSR Academy of Sciences, 142, 6, 1239-1242 [in Russian].

7 Berezin, F.A. \& Shubin M.A. (1983). Uravnenie Shredinhera [The Schrödinger equation/. Moscow: Izdatelstvo MHU [in Russian].

8 Boimatov, K.Kh. (1982). Asimptotika spektra ellipticheskoho differentsialnoho operatora v vyrozhdennom sluchae [Asymptotics of the spectrum of an elliptic differential operator in the degenerate case]. Doklady $A N S S S R$ - Reports of the USSR Academy of Sciences, 266, 1, 14 [in Russian].

9 Yang, C.F. (2010). New trace formulae for a quadratic pencil of the Schrödinger operator. Journal of Mathematical Physics, 51, 33506.

10 Zettl, A. (2005). Sturm-Liouville theory: Mathematical Surveys and Monographs. American Mathematical Society, Providence, 121.

11 Iwabuchi, T., Matsuyama T. \& Tanigichi, K. (2017). $L^{p}$-boundedness of Schrödinger operators on an open set of $R^{d}$. New Trends in Analysis and Interdisciplinary Applications. Selected contributions of the $10^{t h}$ ISAAC congress, Springer Int. Publ., 319-325.

12 Lidskii, V.B. (1960). Nesamosopriazhennyi operator tipa Shturma-Liuvillia s diskretnym spektrom [Nonselfadjoint Sturm-Liouviele operator with discrete spectrum]. Trudy Moskovskoho matematicheskoho obshestva - Proceedings of the Moscow Mathematical Community, 9, 45-80 [in Russian].

13 Guzman, M. (1975). Differentiation of integrals in $R^{n}$. Berlin |Heidleberq|. New York: Springer-Verlaq.

14 Otelbaev, M. (1983). Koertsitivnye otsenki i teoremy razdelimosti dlia ellipticheskikh uravnenii v $R^{n}$ [Coercive estimates and separability theorems for elliptic equations in $R^{n}$. Trudy Matematicheskoho instituta imeni V.A. Steklova - Proceedings of the V.A. Steklov Mathematical Institute, 161, $195-217$ [in Russian].

15 Muratbekov, M. \& Otelbaev, M. (2011). On the existence of a resolvent and separability for a class of singular hyperbolic type differential operators on an unbounded domain. Eurasian mathematical journal, 7, 1, 50-67.

16 Akhieser, N.I. \& Glasman, I.M. (1963). Theory of linear operators in Hilbert space. Originally published: New York: Unqar Publ. 